\title{
The Application of Legal-Statistical Method in Analysing Manufacturing Property's Institutional Development
}

\author{
Submitted 08/03/19, 1st revision 02/04/19, $2^{\text {nd }}$ revision 15/05/19, accepted 09/06/19
}

\author{
T.V. Shatkovskaya ${ }^{1}$, I.A. Isayev ${ }^{2}$, T.V. Epifanova ${ }^{3}$, M.A. Ismailov ${ }^{4}$ \\ Abstract:
}

Purpose: The study defines the specifics and opportunities, that arise due to the application of statistical method in judicial research of manufacturing property.

Design/Methodology/Approach: The authors put the ground of the study on the aggregation of a vast spectrum of statistical data and indicators of patent activity of leading countries in the sphere of technological innovation.

Findings: The authors outlined the main tendencies of legal regulation of scientific and artistic results of intellectual property development and define the specifics and opportunities that arise due to the application of statistical method in judicial research of manufacturing property. Lack of coordination of approaches to protect manufacturing property on the international level, obstructs the development of patent activity amongst the members of the Paris Convention and significantly reduces the effectiveness of the current patent system.

Practical implications: Authors' development could be utilized in future developments of Russian institute of manufacturing property and its legal framework.

Originality/Value: The contribution of the article is the comprehensive analysis of legal background of intellectual property institute and its development prospects.

Keywords: Manufacturing property, invention, intellectual property, blockchain, patent rights, intellectual rights, trademarks, exclusive rights.

JEL codes: $C 10, O 34$.

Paper Type: Research article in Special Issue dedicated to Russian Economy.

Section 5: Law, Constitutional, Social.

Acknowledgement: This publication is supported by RFBR, project 18-29-161124.

\footnotetext{
${ }^{1}$ Doctor of Law, The Russian Presidential Academy of National Economy and Public

Administration, Professor Rostov State University of Economics (RSUE), Rostov-on-Don, email: shatkovskaya.tv@gmail.com.

${ }^{2}$ Doctor of Law, Professor, Head of the Department of History of the State and Law of

Kutafin Moscow State Law University (MSAL), Honored Scientist of Russia, e-mail: kafedraigp@mail.ru

${ }^{3}$ Doctor of Economics, Professor Rostov State University of Economics (RSUE), Rostov-onDon, Russian Federation, e-mail: profepifanova@gmail.com

${ }^{4}$ Doctor of Law, Professor at the Department of theory and history of state and law, Chechen State University, e-mail: adako28@yandex.ru.
} 


\section{Introduction}

Interconnection between the legal field and economics is explained by the increasing need for legal order of economic relationships. Particular attention is paid towards property related relationships that serve as guarantee of entrepreneurial activity and economic independence not only for groups of parties, but also for separate individuals. Property is the point of contact for legal and economic spheres of public relations, results in the application of special inter-disciplinary measures of scientific analysis, not common to the legal research. Thus, during the process of modelling of judicial constructions, intended for protection of intellectual property, it is important to account that such constructions should not contain commercial turnover or obstruct business development.

Special attention should be given to the legal institute of manufacturing property. Its legal registration happened in the $21^{\text {st }}$ century, and without any significant amendments it is still applied to date, without the needed adaptation for the digital and modern market conditions. Such approach reflects the overall tendency of modern jurisprudence for logical-dogmatic constructions, completely detached from the socio-economic reality. Overcoming this "detachment" with contribute towards expansion of use of statistical research methods. Being the untypical method of internal legal analysis, it also allows to obtain the relevant information for studying mass legal developments and processes, as well as the establishment of connection between legal regulators and results of judicial action, reflected in absolute and relative indicators, coefficients and other data. In modern jurisprudence (civil rights sphere in particular) the given method is applied very rarely - mainly for the analysis of judicial activity. Furthermore, we believe that legal-statistical approach allows to precisely model settled judicial constructions and forecast their development.

\section{Specifics in Legal Research of Manufacturing Property}

In order to expose the spectrum of opportunities that arise due to the use of statistical method of analysis in the sphere of manufacturing property regulation it is necessary to mention some of the criticism for such method in the legal sphere.

First, legal-statistical method is a system of methods and specifics of legal analysis of quantitative characteristics of government-legal phenomena, in order to expose their qualitative specifics, fundamental development tendencies and qualities that contain legal significance.

Second, quantitative indicators collected and analysed with the use of legalstatistical method should be organised according to its common features, that has a qualitative interpretation, allowing to expose the characteristics of the investigated object. Thus, when analysing manufacturing property, this indicator is the number of 
applications made for one or the other type of intellectual activity (IA) in order to obtain a patent.

Indicators, sorted accordingly to the stated features, allow for formulation of detailed conclusions, regarding the dynamics, intensity and results of scientifictechnological activity that contain commercial value. It also allows to evaluate the adequacy of government and private investment, as well as the relevance to the modern technological challenges.

Third, quantitative indicators, collected with the use of legal-statistical methods, reflect the changes in the qualitative features of investigated object and the main tendencies in the development of scientific-technological sphere. For example, the analysis of the quantity of globally issued patents allows to expose the following statistical conformity: the increase in the number of patents leads to the strengthening of the subjective component, in the process of defining the criteria of patent eligibility amongst manufacturing property and therefore increases the risk of disputes regarding the issued protective documents. It is possible to forecast, that the simplification of registration procedures and reduction of patent fees will result in the increasing number of applications to obtain protective documents, simply due to existence of unpatented inventions and rising innovation activity.

Furthermore, increases in the number of patents affects the qualitative features of manufacturing property objects. In fact, the growth in the number of patents for innovations complicates the valuation of their innovation level, due to the expansion in volumes of global technological development. This lengthens and intensifies the patent expertise, as well as increases the share of dependent innovations. Number of registered instances of exclusive rights transfers for the objects of manufacturing property to the subjects of entrepreneurial activity, as a result of signed agreements of alienation or transfer of exclusive rights, reflect significant changes or established tendencies of commercialization of intellectual rights.

Indicator of effectiveness of investments funds for the scientific research is seen in the level of government patent activity. Its calculation is based on a whole range of coefficients: innovation activity (number of patent application per innovation per 10,000 people in population), self-containment, defined by the ratio of the number of domestic applications to the global number of patent applications.

Fourth, two-level model of legal protection of manufacturing property (international and national level) require the collection of several statistical indicators, in order to implement objective analysis of influence of domestic factors on the development of the considered institute, as well as to formulate a complex picture of real conditions of the object of the study. Success in solving the abovementioned tasks relies on the right selection of the methods of legal-statistical research. In fact, at the national level, the need for use of the method of selective investigations, statistical observations and quantitative analysis. International research should be conducted 
via the methods of modelling, non-uniform observations, collection of analytical groups of data, complex analysis of indicators, comparative statistical analysis, comparison of statistical data.

In addition, we believe that the range of methods and approaches, not directly related to the statistical method, is important for the fully-fledged legal-statistical investigation in the manufacturing property sphere. Thus, sociological questionnaires are not only a good method to collect the information of the nature of utilisation of manufacturing property objects, but also a tool to establish connection between qualitative characteristics and their protection. For example, conducting a sociological questionnaire needs to be considered as a single method to collect representative data on the brand strength of a trademark.

Furthermore, we consider the connection between statistical method and forecasting to be equally strong. Scientifically backed systematisation of relevant statistical indicators and their dynamic rows, should become the basis for the method of composing planned events and implementation of forecasting analysis of their realisation. It may also be applied in preparing the documents of legal forecasting (programs, strategies, plans, doctrines etc.). One of the simplest approaches of such analysis is extrapolation, which is composed of the transfer of past and present indicators, that impact the object being investigated in the future period, as well as all the later instances of decision-making, in order to improve the normative-legal regulation in the sphere of manufacturing property.

For example, Ministry of Education of the Russian Federation has made a forecast, predicting that the number of patent applications from the Russian universities will grow by $60 \%$ in the nearest future. However, the chances of such forecast are being undermined by the Rospatent data, which suggests that over the last 5 years, the number of application has contracted by $20 \%$ (including the numbers coming from the Russian Universities decreasing by 13.8\%) and in 2017 these indicators were at the minimum level and accounted for 22,7 thousand applications (RUPTO MINOBR, 2019). A small growth in the number of applications in 2018 amounted for $5.4 \%$ which has no serious impact on the current situation.

For comparison, it is important to note, that according to the data from the World Intellectual Property Organization (WIPA), global tendencies are as follows: number of applications for inventions has increased by $108.3 \%$, useful models $-129 \%$ and manufacturing samples $-108.3 \%$ (WIPO, 2019).

\section{The Application of Statistical Method for the Analysis of the Definition "Manufacturing Property"}

Legal-statistical analysis of manufacturing property contains a number of phases, including the establishment of real state of the following phenomenon, formulation of the model of manufacturing property and the following reveal of its development 
tendencies. It is important to establish statistical indicators (especially the official statistical reports) that define qualitative characteristics of manufacturing property, as well as comparison of normative approach and its actual definition.

Traditionally, the juridical literature assumes that the definition of "manufacturing property" is formulated in the Convention for manufacturing property protection as of $20^{\text {th }}$ of March 1883 (Gavrilov, 2015). It is difficult to agree with, since the first page of the Convention only lists the legal objects (inventions, useful models, manufacturing samples, trade-marks, brand titles, origination titles of the product, preventions of unlawful competition), which are supported by the rights protection. Consequently, the Convention does not provide the definition, but simply lists the objects that are protected in the form of manufacturing property (Paris Convention for Manufacturing Property Protection).

Given this, the terminology formulated by the Convention cannot address a vast variety of criticisms. First, the reference to manufacturing as a sphere of utilisation of protected objects of civil relations. At the following stage of economic development, the turnover of objects of manufacturing property contains all the spheres of human activity, related to the creation and commercial use of technical Results of Intellectual Property (RIP), that possess the qualities of common use and potential to bring benefits not only to the rights holder, but also to the producers that contain the intellectual product and the potential consumers. To paraphrase the statement of E.A. Sukhanov, the definition of "manufacturing property" is conditional, since it does not relate to the definition of property and is not exclusive to manufacturing (Sukhanov, 2008).

Second, the establishment of a contained list of objects, the rights that are protected under the regime of manufacturing property contradicts the modern concept of intellectual rights, that assumes rights protection to any creative result of intellectual activity from the moment of its emergence. For example, in the Russian Federation (RF) the following approach is supported in p. 44 of the Constitution of the RF.

As a result, the newly created scientific-technical results and conditional definition with certain juridical value, like commercial designations, production secrets (knowhow) cannot be defined as commercial property in accordance to the Convention. It is important to point out, that the listed RIPs are supported by the laws of legal protection. However, there exists several creative results that have the potential of protected objects, without any normative expression. For the collection and analysis, Federal Institute of Government Statistics of the Russian Federation (Rosstat) has introduced a definition "non-patented inventions", which includes the following scientific-technological results: those including an application, with absence of patent for the invention; the application was not performed in order to preserve the secrecy of the product information; those related to the fields of bio-engineering and pharmacology. 
We do not agree with the view point of the authors, who propose for the inclusion of this category into the scientific procedures and its legislative support, since Rosstat demonstrates the potential for controversies at the international level and collusions between the regimes of legal protection and actual demands from the innovations market, which can be shown through the use of statistical method.

Finally, the main deficiency of the Convention is the absence of the necessary international standards in defining the patent compatibility of the objects of manufacturing property, including commonly accepted qualities which should be present amongst all the results of intellectual activity, protected in the form of manufacturing property.

Given the above-mentioned deficiencies, we realise that the definition of "manufacturing property" that has emerged in jurisprudence during the epoch of connection of scientific knowledge and manufacturing production, which became the precursor of the "technology" category, needs to be preserved as a common definition for the protected RIPs, possessing commercial value in the scientifictechnological sphere. It is important to point out, that the Patent Law of the People's Republic of China, which since 2011 has become an undoubtable leader in terms of the number of patent applications (more than 1 million per year), uses the commonly accepted definition of innovation achievement (General Introduction to the Third Revision of the Patent Law of the People's Republic of China and its Implementing Regulations), while the modernization of the patent legislation is carried out in the direction of unification of criteria of patent compatibility amongst inventions.

Therefore, manufacturing property may refer to non-material property in the form of intellectual products or subjective intellectual rights, protected by a patent or some other form of documentation, registered formally, possessing legal capabilities to participate in the civil relations and with the potential to be used in the manufacturing and scientific-technological sphere.

The following approach contributes towards a concrete separation of objects that contain patent capabilities, yet without the support of legal protection of international acts and national legislation regarding intellectual property, that are at the stage of application or registration, as well as objects under patent protection. Such classification allows to establish legal regimes for protection of rights holders of all the above-mentioned objects for their participation in civil relations. This allows to establish qualitative characteristics of manufacturing property, optimize the procedures of registrations and speed up the implementation of technical RIPs into the civil relations.

\section{The Use of Statistical Method for Normative Forecasting of Manufacturing Property's Institutional Development}


Analysis of statistical data for the development of manufacturing property institution allows to highlight several important tendencies. A simple increase in the public and private expenditure for technological innovation does not equal to the growth in the number of patent applications for innovation, useful model or manufacturing samples. According to the Rosstat data, domestic R\&D expenditure in the Russian Federation is estimated at 1,019.2 billion RUB, which equals to 1.11 GDP (out of which 66,2\% is government funded, 30,2\% is enterprise funds) (Gorodnikova, 2019). Technological innovation expenditure of SMEs in Russia has increased by $20 \%$ over the past 5 years, and now equals to 20 billion RUB.

Furthermore, in the period of 2016-2017, according to the Rospatent data, there is an observed decrease in the number of innovation application by $12.3 \%$, in useful models by $4.2 \%$. Only with respect to manufacturing sample applications there is an observed positive dynamic in the period between 2000 and 2017. Their number has increased 2.8 times. However, legal-statistical analysis shows that with respect to criteria of self-sufficiency and dependency, the level of patent activity in manufacturing samples is also decreasing. Thus, the share of domestic and international applications in 2000 was at $83.8 \%$ and $16.2 \%$, while in $2017-41.1 \%$ and $58.9 \%$.

It is obvious, that the efficiency indicators for financial expenditures should be the return on investment in the form of domestic utilization of intellectual products and the following benefits (income) attributed to the third parties. Statistical data demonstrates positive dynamic in the increasing number of RIPs used in the Russian Federation 2.6 times during the period between 2005 and 2017. Given this, $45 \%$ of the utilized RIPs are innovations, second place is taken by programmes for electronic computers - around 25\%, followed by useful models - just over $16 \%$. Prioritised spheres of utilisation are manufacturing production (around 44\%) and the sphere of scientific research and development (around 32\%) (Annual report, 2000; 2017).

However, the analysed Rospatent data on the number of registered orders for exclusive rights for the innovations, useful models and manufacturing samples, allows us to establish, that the growth indicators for the utilisation are related to the imported RIPs. In the period between 2013 and 2017 in the Russian Federation, the number of registered orders, which in fact represents the number of agreements for the transfer of exclusive rights to the objects of manufacturing property has decreased from 3123 to 2991.

The above-mentioned indicators confirm that a simple increase in the financial expenditures in R\&D and scientific-technological development cannot be viewed as a self-sufficient measure to increase the level of effectiveness and commercialisation of manufacturing property sphere. This conclusion may seem obvious, however it still requires a basis, as according to the statistical data in 2015, around $15 \%$ of all organisations conducting innovation activity in the manufacturing sector of the 
economy of the Russian Federation have considered a lack of internal funds and financial support from the government, as a main factor hindering technological innovation. For comparison only $3.5 \%$ have mentioned the lack of normative-legal regulations (Gorodnikova et al., 2018).

Therefore, it is important to highlight, that in the international rating for network preparation, in the context of Global Economic Forum in 2016, Russia was placed $88^{\text {th }}$ out of 139 countries based on normative foundation conditions. Based on the indicator of intellectual property protection, Russia was ranked $123^{\text {rd }}$ (D-RUSSIA, 2016).

Furthermore, the analysis of the applications for the variety of manufacturing property objects allows us to expose the effectiveness of scientific-technological research and development, via establishing the level of government patent activity, as well as indicate the disproportionality in the economic development. The level of government patent activity is calculated through the share of applications related to manufacturing property objects to GDP. On the basis of WIPA data for the $3^{\text {rd }}$ of May 2018, the leading countries in terms of the level of patent activity are South Korea (innovations, manufacturing samples) and China (trademarks). For example, South Korea has overtaken USA in this indicator, which was the leading country in terms of active patents in 2016, by 5 times. The ratio of trademarks in China is 8 times greater than in the USA, and 3.2 times greater than in Russia.

In order to characterise the growth of the Russian economy, only the growth in the level of trademarks in the period between 2000-2017 may be considered positive (2.7 times). However, if we account for the decreasing level of patent activity regarding innovations and useful models, the disproportion is striking - the level of trade outweighs the manufacturing sectors of the economy. In fact, it is the manufacturing activity in the Russian Federation that in 2017 utilised applied RIPs 138 times more than the trade sphere (Annual Report, 2017).

The analysis of Rospatent activity allows us to conclude, that the imperfections of the current patent system cannot be resolved through simple speeding up of registration procedures. Thus, Rospatent statistics for the 2016 and 2017 suggest the reduction in the waiting time for the application considerations from 10,43 months to 8,37 months (average time for application consideration for useful models and manufacturing samples is around 9 months (RUPTO, 2018). It is important to highlight, that the overall decrease in the time for registration procedures and high level of service provided by Rospatent (judicial review of 0,5\% of Rospatent actions has not resulted in the increasing number of patent applications (RUPTO, 2016).

The solution to the problem of modernization of the patent system may be found in the development of manufacturing property rights in the two directions: unification of the patent registration procedures amongst the Paris Convention members and their simplification via a wide implementation of cutting-edge technologies (such as 
blockchain), which can provide a high level of protection and speed up the registration processes.

The first direction is being actively promoted due to the transfer of Paris Convention member-countries onto the patenting system on "first come first served" basis, which is popular on the territory of all the leading countries in terms of innovation development. Such statement can be easily supported, since USA has also changed its system after the implementation of Leahy-Smith America Invents Act, as well as the compliance of American legislation with the international standards.

The significance of blockchain technology for the development of manufacturing property is evident in the fact that it allows to simplify registration procedures and background checks for RIPs, which may not be supported by legislation; management and commercialization of RIPs by the rights holder without broker involvement, which simplifies and makes the intellectual products turnover cheaper; turnover of intellectual resources on the mutually beneficial conditions for the owner and the consumer; solution of problems related to transactions, such as confidentiality, security, data wholeness, reduction of transaction costs, automatic agreements via smart-contracts, payments, interactions and etc. (Shatkovskaya, 2018).

The discretion of legal protection of scientific-technological results in the form of concrete objects of patent law, which ensure the individualization of participants of commercial turnover, their products, services and enterprises complicates and limits the protection of right holders, users and consumers of intellectual property in the scientific-technological sphere. Analysis of statistical data shows, that during the entrepreneurial valuation of protection methods of scientific research, the priority is given to the methods that do not require registration, in order to preserve commercial secrets and secrecy of know-how (Figure 1).

The first step to overcome the discretion of manufacturing property protection is the development of universal criteria and legal regimes for the two main groups of patented objects and means of individualization. Regarding the patented objects in the Russian Federation, the development is already happening. Thus, since 2015 the civil legislation includes the qualitative characteristics of innovations and useful models, such as novelty and manufacturing applicability, which have the same meaning. This significantly simplifies the patent application procedures for the following objects.

\section{Results of the Study}

Therefore, legal-statistical research of the manufacturing property institute allows highlighting a number of negative and positive tendencies in the modern development of legal regulations of the manufacturing property institution. 
Figure 1. Relationship between compulsory registration and those without compulsory registration protection methods for scientific-technological developments for enterprise valuation in the manufacturing sector of Russia (Gorodnikova et al., 2018).



The negative tendencies include the volume and legal means of protection of the given institution. Thus, on the one hand, the current norms of international and domestic (in the example of the Russian Federation) legislation, artificially limits the sphere of activity of legal protection, imposing national barriers and boundaries for the manufacturing activity of the authors. Furthermore, the established discretion of the protected objects, in the sense that manufacturing property protection may only be applied to the scientific-technological results, which comply with the current demands towards innovation, useful models, manufacturing samples and logos, that contain the properties of trade-marks, firm name or information about the origination of the product. As a result, the creative, technological solutions, that possess commercial value and are technically used in the innovation development, protected by the author while satisfying the legal demands of enterprises are left behind the legal boundaries.

On the other hand, the establishment of subjective-evaluative definitions in the form of conditions for exclusive and patent rights, complicates and lengthens the registration procedures for the objects of manufacturing property, as well as provokes the contraction of patented intellectual assets of an organization, while increasing the number of legal disputes.

For future development of intellectual scientific-technological products in the Russian Federation, there is a negative tendency in the absence of orientation on commercial attractiveness of scientific-technological and construction findings (Vovchenko and Epifanova, 2018). Thus, the stated criteria is absent in the form of compulsory demands to be included in the technological solutions in the number of 100 potential innovations in Russia. For an innovation to be included in this list, it 
should comply with the strategical direction of scientific and technological development set out by the government. Commercial effect from the integration of these developments is considered in the stand-by regime. However, patent holders will be able to break-even on the investments only in the case of commercial attractiveness of the object in the market and its legal protection on the territory of all the members of Paris Convention.

Only when the international community will develop the unified approaches to understanding of "manufacturing property", agree on the universal legal regimes of its protection and overcome territorial barriers to formulate a universal system, the legal protection for manufacturing property will become possible. Furthermore, the solution of this problem is a necessary condition to increase the patent activity of global innovation leaders (Shatkovskaya, 2017). Over the past 5 years, the WIPA statistics demonstrates the absence of growth dynamics amongst all the counties, with the exception of China. The following indicators suggest, that in the conditions of current stage of technological revolution the result will either be the government rejecting its territorial ambitions in the sphere of patenting, of the current patent system will give the way to technological means of protection.

Positive tendencies of manufacturing property development are the global tendency to develop universal criteria for the main groups of manufacturing property (patented objects and means of individualization), acceptance of normative solutions to overcome the discretion of their legal systems, expansion of the list of objects of manufacturing property (production secrets (know-how), selective achievements, commercial titles), as well as unique experience of development and implementation of the unified Eurasian patent for innovations.

\section{References:}

Annual report. 2000. Annual Official Issue of the Russian Agency for Patents and Trademarks. Rospatent.

Annual report. 2013. Annual Official Issue of the Federal Service in Intellectual Property (Rospatent). Rospatent.

Annual report. 2017. Annual Official Issue of the Federal Service in Intellectual Property (Rospatent). Rospatent.

D-RUSSIA. 2016. Russia ranked $41^{\text {st }}$ in rating of network readiness by WEF 2016. Available online: http://d-russia.ru/rossiya-ostalas-na-41-meste-v-rejtinge-setevoj-gotovnostivsemirnogo-ekonomicheskogo-foruma-2016.html.

Gavrilov, E.P. 2015. 50 years since USSR has joined the Paris Convention for Manufacturing Property Protection. Patents and Licenses, 7, 17-22.

Gorodnikova, N.V., Gohberg, L.M., Ditkovski, K.A. 2018. Indicators of innovation activity. Statistical collection, National Research by "Higher School of Economics", HSE.

Gorodnikova, N.V., Gohberg, L.M., Ditkovski, K.A. 2019. Indicators of innovation activity. Statistical collection, National Research by "Higher School of Economics", HSE.

Paris Convention for Manufacturing Property Protection. 1990. Publication № 201 @. Geneva, World Intellectual Property Association. 
RUPTO MINOBR. 2019. Russian universities will increase their patent activity up to $60 \%$. Avaiable online: https://rupto.ru/ru/news/kotyukov-rossiyskie-vuzy-v-blizhayshiegody-uvelichat-chislo-registriruemyh-patentov

RUPTO. 2016. Legal practice on intellectual property as for 2016. Available online: https://rupto.ru/content/uploadfiles/docs/stat_2016_2.pdf

RUPTO. 2018. Comparative analysis of patents' requests. Available online: https://rupto.ru/content/uploadfiles/docs/spravka-sravnenie-tz-iz-pm-po-za-9-mes2015-2018.pdf

Shatkovskaya, T.V., Shumilina, A.B., Nebratenko, G.G., Isakova, J.I., Sapozhnikova, E.Y. 2018. Impact of Technological Blockchain Paradigm on the Movement of Intellectual Property in the Digital Space. European Research Studies Journal, 21(S1), 397-406.

Shatkovskaya, T.V., Solonchenko, A.A., Emirsultanov, Ya.A., Naumenko, Yu.A. 2017. Leading Governments' Legal Initiatives of Innovational Development in the Sphere of Commercialization of Intellectual Products. European Research Studies Journal, 20(3B).

Sukhanov, E.A. 2008. Civil Rights in Russia. Private Law.

TOP100. 2012. Statement on the TOP100 patents of Russia. Available online: https://rupto.ru/content/uploadfiles/docs/polog_100_best.pdf

Vovchenko, N.G., Epifanova, T.V. 2018. Economic and Legal Foundations of Modern Russian Society. A New Institutional Theory.

WIPO. 2019. WIPO IP facts and figures. Available online:

https://www.wipo.int/edocs/pubdocs/en/wipo_pub_943_2018.pdf. 